birthweight at term in the rural Tanzanian village of Ihula. Br J Obstet Gymaecol 1989;96:158-66.

14 Seidman DS, Ever-hadani P, Gale R. The effect of maternal weight gain in pregnancy on birthweight. Obstet Gynecol 1989;74:240-6.

15 Dawes MG, Grudzinskas JG. Patterns of maternal weight gain in pregnancy. Br J Obstet Gynaecol 1991:98:195-201.

16 Altman DG, Hytten FE. Assessment of fetal size and fetal growth. In: Chalmers I, Enkin M, Keirse MJNC, eds. Effective care in pregnancy and Chalmers 1, Enkin M, Keirse MJNC, eds. Effective care in pregn

17 Newcombe RG. Development of obesity in parous women. $\mathcal{f}$ Epidemiol Community Health 1982;36:306-9.

18 Greene GW, Smiciklas-Wright H, Scholl TO, Karp RJ. Postpartum weight change: how much weight gained in pregnancy will be lost after delivery? change: how much weight gained
Obstet Gynecol 1988;71:702-7.

19 Samra JS, Tang LCH, Obhrai MS. Changes in body weight between successive pregnancies. Lancet 1988;ii:1420-1.

20 Rookus MA, Rokebrand P, Burema J, Deurenberg P. The effect of pregnancy on the body mass index 9 months post partum in 49 women. Int $\mathcal{F}$ Obesity 1987;11:609-18.

21 Billewicz NZ, Thomson AM. Body weight in parous women. Brf Prev Soc Med 1970;24:97-104.

22 Cederlöf $R$, Kaij $L$. The effect of childbearing on body-weight. A twin control study. Acta Psychiatrica Scand 1970;219 (suppl):47-9.
23 Taffel SM, Keppel KG. Advice about weight gain during pregnancy and actual weight gain. Am f Public Health 1986;76:1396-9.

24 Palmer JL, Jennings GE, Massey L. Development of an assessment form. Attitude towards weight gain during pregnancy. I Am Diet Assoc 1985;85: 946-9.

25 Orr RD, Simmons JJ. Nutritional care in pregnancy. The patient's view. 1. Amount, type and sources of dietary advice and treatment. $\mathcal{A}$ Am Diet Assoc 1979;75:126-31.

26 Hytten FE. Restriction of weight gain in pregnancy: is it justified? foumal of Human Nutrition 1979;33:461-3.

27 Campbell DM. Dietary restriction in obesity and its effect on neonatal outcome. In: Campbell DM, Gillmer MDG, eds. Nutrition in pregnancy. Proceedings of the tenth study group of the Royal College of Obstetricians and Gynaecologists. London: RCOG, 1983:243-50.

$28 \mathrm{MacIntyre} \mathrm{S}$. The management of food in pregnancy. In: Murcott A, ed. The sociology of food and eating: essays on the sociological significance of food. Aldershot: Gower, 1983:57-72.

29 Hytten FE. Weight gain in pregnancy. In: Hytten FE, Chamberlain G. Clinical physiology in obstetrics. Oxford: Blackwell, 1980:193-233.

(Accepted 8October 1991)

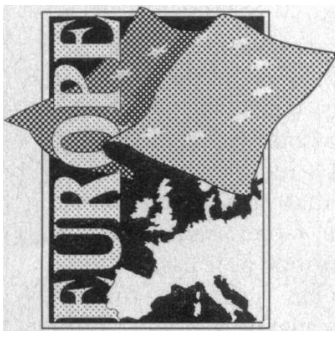

This is the eleventh in a series of articles looking at medical issues in Europe
National Addiction Centre, Institute of Psychiatry, London SE5 8AF

Michael Farrell, MRCPSYCH, research senior registrar

Drug Dependence Clinical Research and Treatment Unit, Bethlem Royal Hospital, Beckenham BR3 3BX

John Strang, MRCPSYCH, consultant psychiatrist

Correspondence to: $\mathrm{Dr}$ Farrell.

BMf 1992;304:489-91

\title{
Medicine in Europe
}

\section{Alcohol and drugs}

\author{
Michael Farrell, John Strang
}

There has been an extraordinary diversity of substance problems in Europe, mirroring historical, cultural, religious, and political differences. The nature and extent of the problems associated with substance use vary, as do the moral, medical, social, and scientific responses.

In northern Europe people have drunk spirits, leading to a pattern of intermittent and explosive drunkenness, while in the south wine drinking has been integrated into a way of life with little public drunkenness and high risks of liver cirrhosis. In between there has been a belt of beer drinkers in Germany, the low countries, and Britain. The north has favoured Alcoholics Anonymous and fostered the temperance movement, while in France moderation was defined until comparatively recently as not more than a litre of wine a day.

A myriad of groups and organisations are involved in alcohol and drug policy in Europe, but the lack of a health directorate has rendered much of the data and issues impenetrable. Data need to be collated on a community wide basis. The Maastricht summit has committed the European Community (EC) to some responsibility for health, ${ }^{1}$ and drugs have been incorporated in the remit that will take effect in 1993.

\section{Alcohol}

The rates of alcohol consumption and alcohol related problems vary greatly. Rates of consumption are higher in southern Europe. A consensus has developed among policy makers that the level of alcohol related problems in a society reflects the level of consumption, ${ }^{23}$ which is affected by cost and availability. ${ }^{4}$ Traditionally, the northern European states have imposed higher levels of taxation and restricted availability. These are the countries which have invested more in medical and social research on alcohol and alcohol related problems and taken the problems more seriously by developing prevention and treatment programmes. Despite such polarities France has reduced consumption from $17 \cdot 3$ litres of $100 \%$ alcohol a head in 1970 to 13.2 litres a head in $1989,{ }^{4}$ and Italy has shown an even more dramatic reduction, from 16 litres to 9.7 litres a head between 1970 and 1989. Meanwhile, some of the countries with a low consumption have moved up - for instance, the United Kingdom moved from $5 \cdot 3$ to $7 \cdot 3$ litres a head between 1970 and $1989 .{ }^{4}$

\section{TAXATION}

McGuinness has reviewed the impact of proposed EC legislation on alcohol consumption in the United Kingdom. ${ }^{5}$ The right of individual countries to determine their own policy for controlling alcohol consumption and to modify it in the light of the rising incidence of alcohol related mortality and morbidity encapsulate some of the difficulties of European integration. ${ }^{6}$ The proposed legislative change aims to introduce the single internal market to remove trade barriers. The community wants to standardise the legislation on the production, packaging, and presentation for sale of goods, and it is in this remit that standardised health warning labels and standard measures may be introduced on alcohol and tobacco products.

The original discussion of the single internal market and fiscal harmonisation failed to recognise the important role of alcohol taxation as an element of health policy. It was originally proposed to have a single rate of duty for each product group in all member states, but after considerable protest the European Commission relented to allow a $10 \%$ range to take greater account of the health aspects of alcohol consumption. According to McGuinness this fundamentally conceded the connection between alcohol taxation and health. Having moved down this path the commission has now stated that it will allow each country to determine its own level of taxation on substances that may influence the nation's health.?

In the original discussion the acceptance of differential rates of taxation was viewed as a transitional arrangement where ideally countries would evolve to a position of equalisation. Countries with high tax rates may move down to come in line with other member states. The free flow of low cost alcohol across borders is likely to have marginal effect on national consumption rates in the United Kingdom but may pose problems for other countries.

\section{CONSUMPTION AND MORBIDITY}

A limited amount of collated data exists on European morbidity and mortality related to alcohol consumption. The table shows the most recent reports on national rates of alcohol consumption. The most 
graphic representation of the relation between alcohol consumption and death rates from cirrhosis of the liver in the mid-1970s represents the crude polarisation of consumption between northern and southern Europe (fig). ${ }^{8}$ Governments face continuing political difficulties when reconciling the conflicting needs of the alcohol industry and revenue collection on the one hand and the needs of the general health of the population on the other hand. Some degree of compromise has been established but it is not clear how individual governments will fare in a larger Europe against a powerful multinational corporate lobby pushing the health issues of alcohol further down the political agenda.

A range of laws deal with the consequences of alcohol consumption, such as public order laws, drinking and driving laws, and laws on the medical fitness to drive. ${ }^{6}$ Some of these laws are coming under EC scrutiny.

\section{PRODUCTION, DISTRIBUTION, AND PROMOTION}

The Scandinavian countries have traditionally been the most stringent controllers of production and distribution. Alcohol was rationed in Sweden at one time, and while an interesting case may be made for such an approach on health grounds it is clearly now a politically and socially unacceptable control strategy. The Scandinavian countries continue to have state owned production and distribution enterprises. Eastern European countries such as Poland, Czechoslovakia, and Bulgaria have successful state owned alcohol industries. The changes taking place in many eastern European countries have important implications for the balance between more restrictive alcohol control

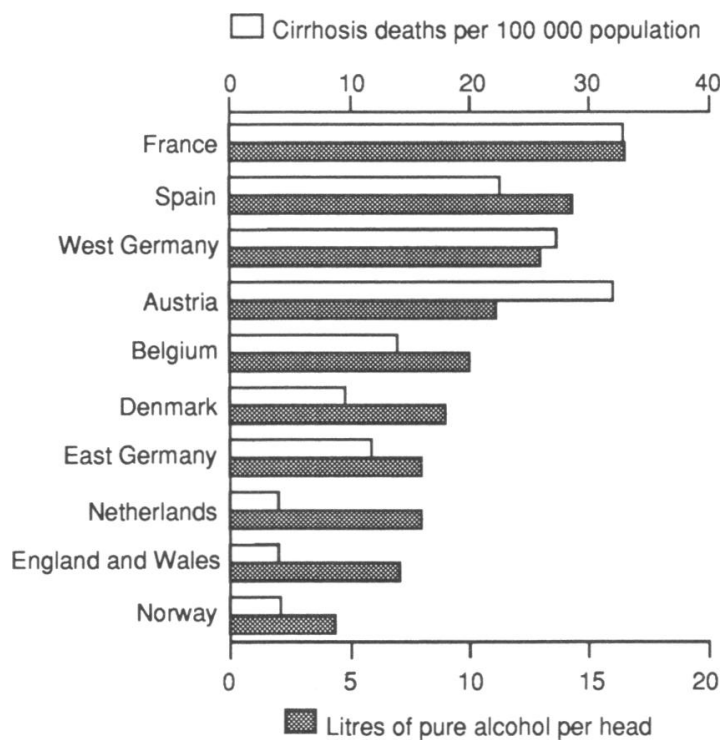

Deaths from cirrhosis of the liver and alcohol consumption in some European countries, mid-1970s

Alcohol consumption per head of population in the European Community (excluding Luxemburg)

\begin{tabular}{|c|c|c|}
\hline & \multicolumn{2}{|c|}{$\begin{array}{c}\text { Litres of } 100 \% \text { alcohol pe } \\
\text { head }\end{array}$} \\
\hline & 1970 & 1989 \\
\hline Belgium & $9 \cdot 6$ & $9 \cdot 8$ \\
\hline Denmark & $7 \cdot 1$ & $9 \cdot 6$ \\
\hline France & $17 \cdot 3$ & $13 \cdot 2$ \\
\hline Greece* & $5 \cdot 3$ & $5 \cdot 5$ \\
\hline Republic of Ireland & $5 \cdot 9$ & $5 \cdot 8$ \\
\hline Italy & $16 \cdot 0$ & $9 \cdot 7$ \\
\hline Netherlands & $5 \cdot 5$ & $8 \cdot 1$ \\
\hline Portugal & $9 \cdot 8$ & $10 \cdot 2$ \\
\hline Spain & $12 \cdot 1$ & $11 \cdot 0$ \\
\hline Western Germany & $12 \cdot 1$ & $12 \cdot 2$ \\
\hline United Kingdom & $5 \cdot 3$ & $7 \cdot 3$ \\
\hline
\end{tabular}

$\star$ Beer and wine.

\section{European organisations concerned with drug policy}

\section{United Nations}

The United Nations international drug control programme is involved in ratifying international drug control treaties that include Europe as part of its global responsibilities. Most countries have drug control policies ratified by the United Nations.

\section{Council of Europe}

The Council of Europe, established in 1947, has a remit to promote human rights through the European Court of Human Rights in Strasburg. It consists of 24 member states. The Pompidou Group was established in 1972 as a subsection of the council; its work has focused on attempts to develop epidemiological work on drugs in Europe.

\section{European Community}

The European Council (distinct from the Council of Europe) has agreed on the need for a coherent and effective drug control policy at a European level. Within the European Commission President Mitterand of France proposed the establishment of the European Committee to Combat Drugs, which started in 1989 and has advised the European Council that there was a need for a special emphasis on reducing the demand for drugs. It is proposed that this group should establish a European drugs monitoring centre to coordinate information on a Europe wide basis. The ad hoc "Group Toxicomanie" has a leaning towards health issues; and there is a planning group of the European Community's interior and justice ministers, which was originally established to fight terrorism but has incorporated the responsibility of drug enforcement into its remit.

\section{World Health Organisation}

The European office of the World Health Organisation's substance abuse programme aims, like the other organisations, to facilitate coordination and cooperation and is likely to have an important role in forging links between the EC and other European countries.

policies and the broader social liberalisation policies of the new market economies.

The Nordic countries, Switzerland, and France now ban alcohol advertising on public broadcast systems, and all countries have specific guidelines controlling the promotion of alcohol in public broadcasting. A fierce debate has raged on the imposition of controls banning the promotion of tobacco, and a similar move may occur with alcohol. The United Kingdom government continues to be one of the strongest advocates of voluntary agreements rather than imposed legislation.

Other areas of control are licensing laws, distribution laws, and laws on the advertising and promotion of alcohol products. More recently an EC initiative has made proposals for the labelling of alcohol products.

\section{Drugs}

Although the introduction of the single market may loosen internal controls on alcohol consumption in Europe, the problem of illicit drugs has been viewed much more from the perspective of the loss of border controls and the impact that this may have on the supply of drugs - for example, from the newly established eastern European or Balkan route. Enforcement agencies are worried about the abolition of frontier borders and speculate that there will be increased ease of drug movement within and between countries once the outer European border has been crossed.

The diversity of approaches to substance problems is 
more extreme in the illicit drug field. The data on alcohol related problems seem to be limited, but the data on drug related problems are even more scarce. Because of the illicit nature of drug use the figures provided for the prevalence of use of opiates, stimulants, and other drugs are not far removed from guesswork. The 1980s saw Europe flooded with south west Asian heroin' and a rapid rise in the incidence and prevalence of opiate dependence. ${ }^{10}$ This unfortunately coincided with the introduction of HIV to Europe. HIV has made manifest what otherwise could have remained an underrecognised problem and has placed great strain on health care, social welfare, and criminal justice systems. ${ }^{11}$

The north-south divide has curious parallels in the prevalence of HIV among intravenous drug users, with the Mediterranean countries of Italy, Spain, and France experiencing a much larger problem than their northern counterparts. There is no satisfactory explanation of the difference, but the variation in HIV prevalence may be best explained by the difference of time in the original introduction of HIV to the different countries. After the initial dramatic epidemic, recent figures suggest a levelling off since the second half of 1990 in the number of patients newly diagnosed as having AIDS. ${ }^{10}$

The World Health Organisation has just completed an inventory of drug problems in western and eastern Europe, which provides a collated overview of European problems but faces the inherent problem of any estimate of the prevalence of illicit behaviour. The changing situation in eastern Europe has resulted in increased availability of illicit drugs, and there are early reports of a considerable spread of HIV among Polish drug users.

\section{TREATMENT}

A reasonable estimate of opiate use among different European countries would be $1 \%$, excluding the Scandinavian countries, which seem to have a lower rate. ${ }^{12}$ There is a definite disparity in the service response. The expansion of drug services in European countries has been driven by the increased prevalence of drug problems and by the public health implications of HIV. These services range from low threshold methadone programmes to residential rehabilitation treatment programmes. The Netherlands has relied on a harm reduction model with methadone maintenance and low threshold methadone programmes; the British programme has relied on shorter term use of methadone with a mixed range of community and residential treatment programmes. France and Germany are estimated to have no more than 100 to 200 drug users receiving methadone and rely on abstinence in patient or residential treatment models. There is little evidence to correlate levels of treatment with reduced rates of HIV infection. This variation in treatment may cause drug users to migrate. The Netherlands and the United Kingdom have reported numbers of migrant addicts. This has important public health implications.

\section{AVAILABILITY OF NEEDLES AND SYRINGES}

The United Kingdom, the Netherlands, and Switzerland have active needle exchange programmes in an attempt to limit the spread of HIV. Although Italy has had availability of injecting equipment through shops and pharmacies throughout the '80s, HIV has spread among addicts who inject themselves. Germany, France, and Belgium have relied more on the promotion of syringe cleaning techniques but also have retail outlets.
DRUG LEGISLATION

The role of drug legislation and enforcement strategies has been critically reviewed in the past few years. ${ }^{1}$ The link holding European legislation together is that it has been ratified by the 1961 United Nations convention, but different countries perceive the role of the law in differing ways. ${ }^{14}$ For example, in the Netherlands, although possession of drugs for personal use remains an offence, the law is rarely applied. It remains to be seen if such ad hoc arrangements will continue or if there will be pressure to harmonise implementation of the law. It is estimated that $30 \%$ of the European prison population has a drug dependence problem." With the advent of HIV and high rates of HIV in some European prisons there is pressure for a radical overhaul of the role of the criminal justice system in the response to drug problems in society. ${ }^{1}$ Most European countries are moving towards a reliance on the treatment system but there is clearly a limit to this kind of response.

\section{Research}

The EC has developed concerted action programmes to facilitate increased coordination and communication between researchers. The AIDS programme has included some drugs research, but there is a need for better research coordination on substance misuse and the World Health Organisation's Europe office has initiated a project to compile an inventory of European drug and alcohol research centres as the first step towards improving communications and collaboration.

\section{Helpful target}

The adoption throughout Europe of the World Health Organisation's Health for All by the Year 2000 targets for reducing alcohol and drug consumption and containing the spread of HIV would be an important step in implementing effective public health strategies.

We thank Tony McGuiness of the Institute of Alcoho Studies, Professor Griffith Edwards of the National Addiction Centre, and John Witton of the Institute for the Study of Drug Dependence for advice and information.

1 Waldegrave W. The health of Europe. BMF 1992;304:56.

2 Royal College of Psychiatrists. Alcohol - our favourte drug. London: Tavistock, 1986.

3 Bruun K, Edwards G, Lummio M, Makela K, Pan L, Popham RE, et al Alcohol control policies in public health perspective. Helsinki: Finnish Found Ation for Alcohol Studies, 1975 .

4 The Brewers Society. Statistical handbook. London: Brewing Publications, 1990.

5 McGuiness AJ. Alcohol taxation and the European community. London: Institute of Alcohol Studies, 1991.

6 Walsh D. Alcohol related medico-social problems and their prevention. Copenhagen: World Health Organisation, 1982. (Public health in Europe No 17.)

7 Amended proposal for a council directive on the approximation of the rate of excise duty on alcoholic beverages and on the alcohol contained in othe products. Official Joumal of the European Communities No 1990 January 18;33:12 (C12)

8 Office of Health Economics. Alcohol-reducing the harm. London: OHE, 1981.

9 Stimson G. The war on heroin: British policy and the international trade in illicit drugs. In: Dorn N, South N, eds. A land fit for heron. London: Macmillan, 1987.

10 European Centre for Epidemiological Monitoring of AIDS. Quarterly report no 30. Paris: The Centre, 1991.

1 Harding T. HIV/AIDS in European prisons. Geneva: University Institure of Legal Medicine, 1990

12 Council of Europe. Multicity study of drug misuse. Strasburg: Council of Europe, 1987.

13 Nadelman E. Drug prohibition in the United States: costs, consequences, an alternatives. Science 1989;245:939-46.

14 Leroy B. The community of twelve and drug demand. Comparative study of legislations and judicial practice. Brussels: Commission of the European Community, 1991.

15 Farrell M, Strang J. Drugs, HIV, and prisons: time to rethink current policies. BMF 1991;302:1477-8. . 